\title{
PIONEER
}

VOLUME 13, Issue 2, December 2021: 350 - 362

\section{MEANING AND DISCOURSE OF ORAL TRADITION "BASAN" OF HELONG LANGUAGE}

\author{
${ }^{1}$ Maria Osmunda Eawea Monny \\ ${ }^{1}$ STMIK STIKOM Indonesia, Indonesia \\ Imaria.monny@stiki-indonesia.ac.id \\ ${ }^{2}$ Dominikus Tauk \\ ${ }^{2}$ Politeknik Kelautan dan Perikanan Kupang, Indonesia \\ 22dominikustauk@gmail.com
}

*Corresponding author: maria.monny @ stiki-indonesia.ac.id
$\begin{array}{llll} & & \\ \text { Received } & \text { November 22, } 2021 & \text { Revised } & \text { : December 19, } 2021 \\ \text { Accepted } & : \text { December 20, } 2021 & \text { Published } & \text { : December 31, 2021 }\end{array}$

Abstract: This research examined the meaning and discourse of a tradition named Basan. Halliday's approaches of discourse analysis was used in this research, and was organized around three generalized semiotic meanings that relate to social action (field), roles of people (tenor), and organization of the text or sign (mode). Carrying out the maintenance and revitalization of oral literature was done objectively. "Basan" is a rhythmic traditional speech that is uttered with different intonations in order to convey the main points of speech that is spoken according to the context in order to see the meaning contained in each speech and the context associated with the text spoken. The context in oral tradition "Basan" includes place, time, results and message, which begins with an opening and ends with closing, while the meaning that can be applied in the oral tradition "Basan" are lexical and contextual meanings. "Basan" consists of context and flow, those are opening, main utterance, and closing. For its discourse, "Basan" is done verbally (mode), done by the leaders of the village to the guests in social occasion and by the priest to the assembly in religion occasion (tenor), and done in a social interaction and spiritual activities (field).

Keywords: basan, helong language, revitalization

\section{INTRODUCTION}

Revitalization is known as processed, methods, and acts of reviving or reactivate something that was powerless (Kamus Bahasa Indonesia, 2008). Oral tradition as a form of culture in a typical society requires attention to survive especially for young generations. Oral tradition has been passed down as a form of concern for sustaining on life attitudes, good values and beneficial results for younger generation as its successors. It is a treasure that is expected not to be lost in this modern era. Human's cavillation 
continues to experience massive and intensive changes in all aspects ranging from law, politics, economics to socio-cultural. These changes can be observed form cultural transformations, easy access to transportation and communication, to the establishment of bilateral relations between nations, the existence of movement of people from one are to another. Even though these changes occurred insignificantly in a short period of time, due to massive community interaction, these changes are unavoidable because the world has entered an era known as millennial century. Massive community interaction resulting the changes which cannot be separated from the use of language where language components also undergoes changes, although not in all language levels. Changes can be in a positive or negative directions that are unavoidable. Positive changes are constructive while negative changes are destructive. According to (Astika \& Yasa, 2014), oral tradition is a literature that consists of literature expression of people in a culture that is spread out and spoken from generation to generation. Furthermore, (Sastrowardoyo et al., 1985) stated that, culturally speaking, oral literature is a direct and spontaneous expression of the mind of the common people which form the substratum of society. Thus, similarities in themes and styles may be found among different oral literatures from different regions.

As a means of cultural exchange and a component that have a close relationship with culture, language, especially mother tongue needs a special attention. It starts from people who can speak more than one language. This will lead to language selection with the possibility of eliminating the local languages. When speakers of a language speak other languages better than their own mother tongues, and are supported by political and psychological policies, they will think that speaking in a foreign language is a pride. As a result, due to language selection, the mother tongue as the first language will be forgotten. This can be seen easily by the word choices made. People tend to speak using new words to the level that they never use their mother tongue anymore. In this level, it can be a problem if most native speakers do a massive language selection in the society.

Helong, mostly known as Helon, is Kupang and Semau's Central MalayoPolynesian language. Its speakers are interspersed with those of Amarasi. This language has become endangered as a result of its native speakers marrying those who do not speak Helong as result of coming in contact with the outsiders. Helong speakers are found in four villages in the South-Western coast of West Timor, as well as in Semau Island. Gradually, the native speakers of Helong language tend to use the language that has 
affiliation with Indonesian language system although with adjustment in some parts especially in phonology of lexical for proper noun by changing phoneme $/ \mathrm{o} /$ to $/ \mathrm{u} /$, phoneme /e/ to /i/ and phoneme /d/ to /di/, phoneme /c/ to /s/. Language changes or shift in language patterns happens slowly and takes long period of time. This shift of language pattern cannot be observed easily. The shift of language can be observed with the loss of sound in the lingua unit, gemination, dissimilation, metathesis, changes of phoneme structure in a word or sentence (Tauk, 2016). With the inclusion of language elements into Helong language, it will change in Phonology, Morphology and Semantics. This current research focuses on the sound changing process or phoneme changing process as the result of phonology post lexical process. The data were taken from phrases and simple sentences of Helong language. Theory applied in the study was generative phonology. The results of the study showed that there are five processes those are (1) vowel deletion (2) consonants deletion (3) metathesis (4) dissimilation (5) gemination.

\section{REVIEW OF LITERATURE}

Based on the status of local languages in East Nusa Tenggara, the majority has an oral tradition which is an interesting topic to be discussed. This has dominated in the tradition or other kinds of culture. Each society as the owner of its culture has seen the culture as tradition that has been practiced and as the reflection of moral, society, and supranatural relation of the society. In line with that, as in the case of tradition of people of East Nusa Tenggara, people of Helong that mostly live in Kupang District and Kupang City have an oral tradition named "Basan". In the point of view of the people of Helong, "Basan" is a rhythmic traditional speech that is uttered with different intonations in order to convey the main points of speech that is spoken according to the context. The points of speech are done in community activities such as welcoming guests at government activities, traditional institutions, churches and community activities such as welcoming the harvest season and other activity. The relations between oral literature and the local language are separable. Meanwhile, the local language also faces its own problems in its vitality in society. Local languages began to be pushed by the national language (Indonesian), even by foreign languages. The prestige of using local language has been degraded by other languages which in the view of the speakers do not show a certain higher position in their use. That is, the existence of local language is also put into concern 
to affect the existence of oral literature. If the local language faces a setback, it is possible that the problem of oral literature will also increase. In fact, there are fewer and fewer performers of oral literature left. The generation that is currently still as the perpetrators of oral literature is getting old with very few successors.

According to Pilliang in (Wahyuni, 2017), revitalization is an effort or condition to renew and adjust a principle or system to the current conditions and needs of society. In terms of vitality, revitalization is an effort made to increase the vitality of something. It is one of the efforts to protect from something that is categorized as endangered (Mu'jizah, 2018). Thus, it is associated with oral literature in this case, rejung and guritan are efforts to reform and adapt to increase the vitality of the two types of oral literature. Furthermore, language revitalization, also referred to language revival or reversing language shift, is an attempt to halt or reverse the decline of a language or to revive an extinct one. Those involved can include parties such as linguists, cultural or community groups, or governments. Some argue for a distinction between language revival (the resurrection of an extinct language with no existing native speakers) and language revitalization (the rescue of a "dying" language) https://en.wikipedia.org/wiki/Language_revitalization.

A study on the revitalization of oral literature was done by Widyawati (2019) in Tombo Turuk, Manggarai - Flores, East Nusa Tenggara. This tradition serves as a means of disseminating knowledge and wisdom of local community. In addition, Tombo Turuk also functions as a shaper of moral character, belief as well as building norms of local community. This revitalization effort has resulted that adults are re-starting to learn local fairy tales. The local community began to practice Tombi Turak to the younger generation. Besides, this revitalization has succeeded in collecting various local fairy tales and also increased the love of young generation to local fairy tales.

A research on oral tradition was also done by Maria (2018) with the title "Discourse Wawi Wotik Oral Tradition (WTLWW) Ethnic Krowe in Sikka" using a descriptive analytic. The results of the data analysis are reported informally. WTLWW latent functions is as a system of knowledge, unifying medium, a means of social control, education facilities, and economical means. Meaning revealed in WTLWW are (1) the social meaning, (2) economic significance, (3) the political significance, (4) the aesthetic meaning, (5) didactic meaning. The mechanism of inheritance WTLWW ethnic Krowe 
namely natural inheritance mechanism. This study focuses on semiotic theory, and the theory of cultural change. functions manifest and latent functions that can be seen its natural mechanism. While the research of "Basan" focuses on the meaning and discourse analysis contains in it.

A research on discourse analysis was done by (Dea Rifia Bella, 2018). The study focuses on language practices of Puor and Lamalera people in Lembata Island, East Nusa Tenggara, Indonesia. The result shows that, whenever people interact with each other in barter market, both of them have different linguistic forms of vocabularies and dialects. Even though they have different languages, interestingly, they do not use Indonesian language as a lingua franca; they prefer to use their local languages in barter market. The limitation of their linguistic competence in Indonesian language as well as their perception of Indonesian language as a formal language, justifies their preference to local languages. They do not use Indonesian as their lingua franca because they are using another lingua franca that is well-known as a local language in verbal acts combined with pointing gestures. There are linguistic repertoire that is shared among Puor and Lamalera people to transmit messages between them. In other words, language is not understood as a system of sound, but as a social practice. This study focuses on social interaction of barter market and its social practices, while the study of "Basan" focuses on its' meaning and discourse analysis.

\section{METHOD}

Qualitative descriptive research is applied in this research.The phrase qualitative methodology refers in the broadest sense to research that produces descriptive datapeople's own written or spoken words and observable behavior (Taylor et al., 2016). Qualitative descriptive research is applied in this research. Qualitative means that the stages in a study that produces descriptive data. What is produces in the form of written or spoken words from the informant or the behavior of someone who is being observed (Moleong, 2014) . Furthermore, the data collection technique was carried out by listening, recording, and recording techniques. The data collection data was the transcribed, analyzed by formal and non-formal analysis method. In analyzing the data, researchers explain the data based on its context and flow, meaning also on its discourse analysis of field, tenor and mode. 


\section{FINDINGS AND DISCUSSION}

\section{Findings}

The discussion and findings consist of Basan explains about the function and meaning of Basan, context and flow of Basan and the last one the meaning "Basan". Furthermore, the data then analyzed based on its discourse of field, tenor and mode.

\section{Basan}

Basan in the community's view is a rhythmic speech that is uttered with certain intonations in order to convey the main points of the speech that is spoken according to the context. This point can be varied, such as welcoming guests at the government's activities, traditional institutions, churches, and community's activities such as welcoming harvest season and so on. This tradition has just re-developed in Kupang District, especially in Bolok Village in the 2010's. This is due to the fact that not all people speak and not all customary holders can become native speakers of Helong language. In the oral tradition "Basan" which is traced according to the type of ceremony. It cannot be spoken by the speech community who speak Helong language. It is even confirmed that until now only few people can say "Basan" according to the type of ceremony and the right flow. Revitalization is a process to make something is not (or less) empowered (vital) to become more powerful. For this effort, a person or figure or a common consensus in the Helong speaking community is needed, who are empowered and willing to do it continuously not in short period of time. In the revitalization program, it does not have to start from those who are involved in the field to be revitalized.

The oral tradition of "Basan" has a very important role in the conversation of Helong (Helong Mainland). This is because considering that almost every activity always begins and even some activities end with a speech called "Basan". Etymology, "Basan" is a word that undergoes phonological process, namely form the word "given utterance" which means "welcome utterance" the undergoes a process of dissimilation which is characterized by a change in the glottal sound $/ \mathrm{h} /[+\mathrm{con} .,+$ low $]$ to affricative sound $/ \mathrm{s} /$ [con., -son., + mal] in two syllables. So, the term "Basan" means "welcome words". It is important for Helong speakers in every activity, always preceded by "Basan" as a form of respect to those who attend the activity, including government figures, church leaders, as well as ordinary people. Besides, that respect is also aim at the public. The ancestors who have laid a foundation that has moral values, which is part in every activity. 
Furthermore, "Basan" as a form of identity for the speakers of Helong language. This is evidence of character that is manifested through the speech "Basan". If in other tribal or cultural tradition such as "putting the cloth around the neck of the guests" as a form of acceptance, in the Helong tradition, "Basan" is a tradition that shows the identity of Helong language speakers as a form of acceptance in formal activities.

\section{Discussion}

\section{Context and Flow}

Every language has its own system and its uniqueness in general as well as the oral tradition in Helong language especially "Basan". This tradition is considered difficult because of the inability of the speaker to come up with a word or phrase, time, place and object according to the the context. Context of action according to the context and people according to the context as part of a description or phrase or sentence that can support clarity of meaning with events then context becomes an important foothold for "Basan" speaker. For example, the text that has been transcribed below:

text 1

Auk Halonga nga mo dasing nga,

SSg - $\mathrm{N}-$ adi $-\operatorname{con} \mathrm{i}-\mathrm{N}-$ adi

tom se kit li-likw kia me, ma-mamne nia,

adv-prep-1P1-thousand-adj-conj-many-adj

this expression I address to all of you here

text 2

dadar tukun nam kit lat le laok ma lo mo, litun ma lo,

$\mathrm{v}-\mathrm{adv}-\mathrm{N}-1 \mathrm{P} 1-\mathrm{V}-\operatorname{soni}-\mathrm{V}-\mathrm{V}-\mathrm{Neg}-\operatorname{soni}-\mathrm{V}-\mathrm{V}-\mathrm{Neg}$

our presence here is not a coincidence

time

Text 3

molem lesl nest tia lam, kit itung tanan son me, nangan tanan son,

$\operatorname{soni}-\mathrm{N}-\operatorname{scn} \mathrm{i}-\mathrm{adj}-\mathrm{adv}-1 \mathrm{P} 1-\mathrm{V}-\mathrm{V}-\mathrm{adv}-\operatorname{send}-\mathrm{V}-\mathrm{V}-\mathrm{adv}$

however, we are certain and have decided 
Text 4

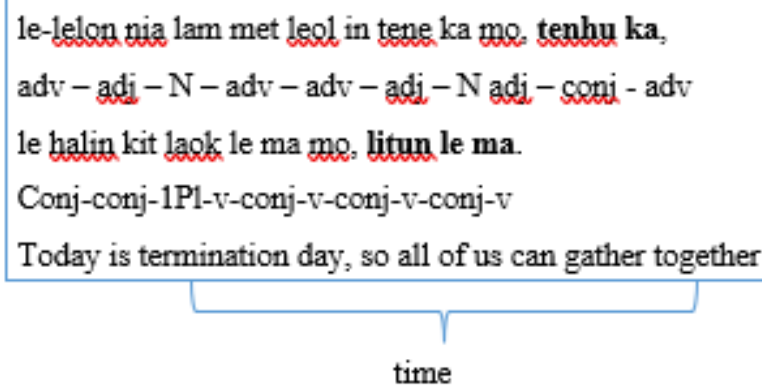

time

Every oral tradition "Basan" is always proceeded by greeting that explains that time of "Basan" has the correlation with community's activities as farmers, fishermen, palm eavesdropper, housewife and so on. This is important to be uttered as a sign of respect for their willingness to take aside their job and responsibility for a social's activity, as a routine or coincidental activity.

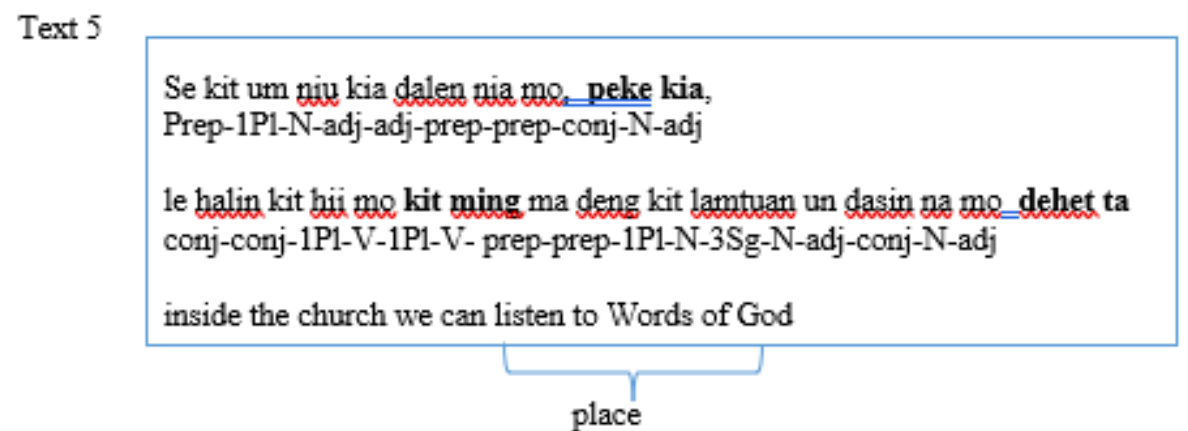

Text 6

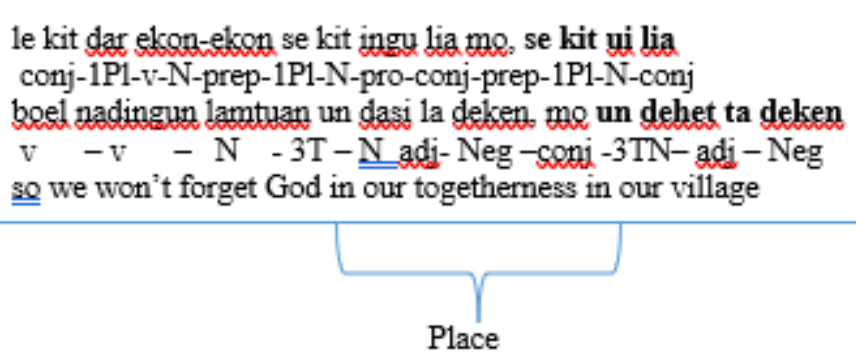

Texts 5 and 6 are texts that show place. This is important in oral tradition to mention thet place where the activity is done because place always has the corelation with the activity. Not all activities can be done in all places and the other way around that not all places can be used as the facility of all activities. This is important due to the diction used that has close corelation with the words or phrase for kinds of activity and its place. 
Text 7

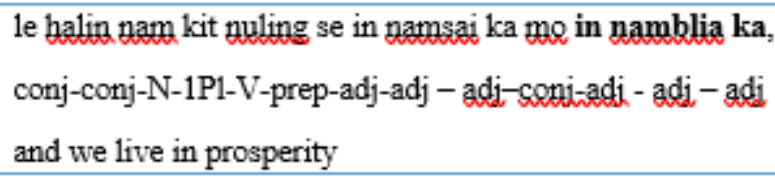

text 8

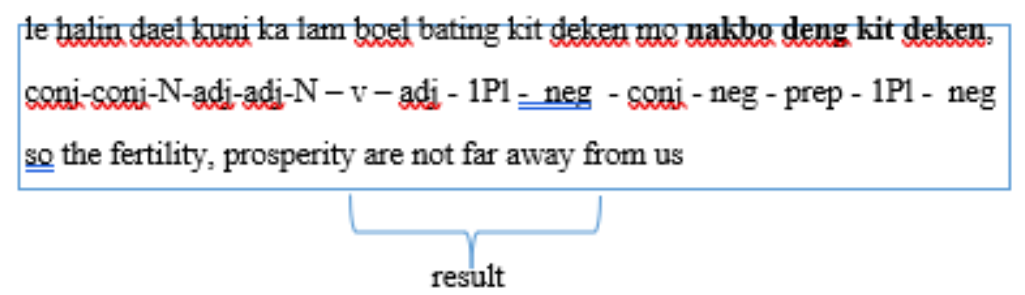

Texts 7 and 8 are the result of the willingness to attend an activity. This is uttered because an utterance is understood as a prayer that they can obtain or are obtaining. This is important as a reassurance for the results that they will receive as the reward of their sacrifices to attend. In other words, they take aside their own responsibility for community's interest. The result of social interest is uttered in a form of words or phrase in accordance with activity and place. This has correlation with others, every word or phrase shows the place and results expected.

\section{Text 9}

ela tia le halin an baun sing nga un piar un ben na tia mo, kit mana sing kai dap adv-adv-conj-conj-n-n-adj-adj-3T-v-3T-n-adj-adv-conj - 1tk-v-v-3T

tilun un dalen na tia,

3T-adv-adj-adv

Prepare yourselves to receive God's words, as a form of our love to God

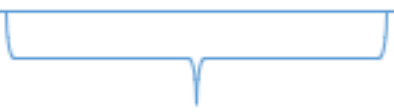

message

Text 10

le halin luli la tom kit deken mo momos napan kit deken.

conj-conj-n-adj-v-1P1-neg-conj-n-adj-1P1-neg

so our sins won't take control on us

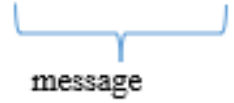


Text 11

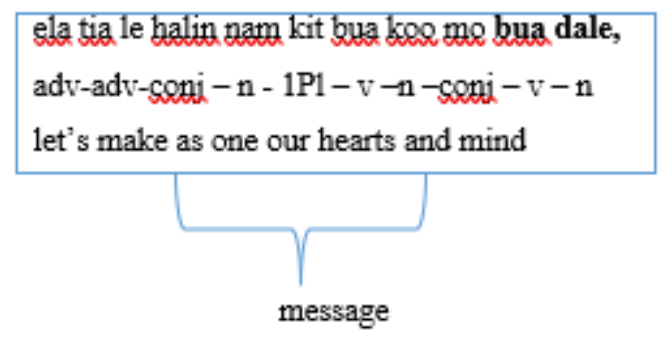

Text 12

$$
\begin{aligned}
& \text { le kit hij mo kit ming } \\
& \text { conj-1P1-v-conj-1P1-v } \\
& \text { so we can listen and notice }
\end{aligned}
$$

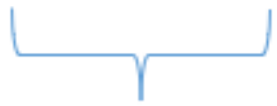

message

Text 13

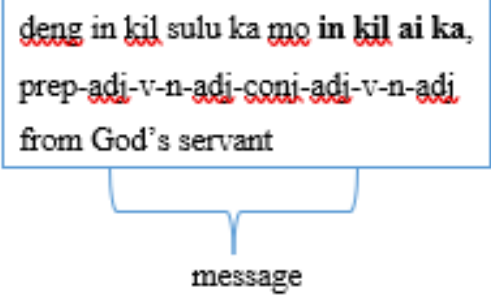

Texts $9,10,11,12,13$ are texts that consist of message. Message is an important part as a strengthening of hopes that will be received. This has the correlation with kind of activity and program of activity. The message will follow the form of activity. If the activity is a spiritual one so the message received is spiritual message. If the activity is about agriculture so the message is about fertility and prosperity. In this part, message also can be categorized into two; those are opening message and closing message. Opening message as mentioned before, while closing message has the correlation with the things that will be received.

Text 14 is a closing text. Mostly, in this part the speaker does not only utter with common words or phrases used in "Basan", but mostly inserted with a conclusion of the activity then close it with phrase or sentence as closing remarks.

Text 14

auk in basan na tuk sea mo pes sea

1T-adj-v-adj-v-adv-conj-v-adv

Closing

"That is all of my speech" 


\section{Meaning}

Lexical and contextual meaning become important things in every utterance of "Basan", because not all words or phrases in the texts of "Basan" has lexical and contextual meaning. So, it is important to understand and placing the words or phrases that have lexical and contextual meaning on its place. For example, some words and phrases in oral utterance "Basan" that has been transcript as follows:

1) se kit um niu kia dalen mo, hena niu peke kia prep-1Pl-N-adj-nm-prep-prep-N-adj-N-adj in our house clean that in and resting clean source this "inside the church and around the church"

Words and phrases in italic and bold are words that must be translated into contextual meaning, phrase 'um niu' means clean house which means church, this phrase is translated lexically dan the second word 'hena' means place for the resting of flocks, but in its contextual meaning means calmness. So, these words are translated in its contextual meaning that has the meaning that getting close to the church that gives you calmness. While, other words or phrases in the sentence above is translated lexically.

2) dael kuni ka lam boel bating kit deken mo nakbo deng kit deken

$\mathrm{N}$-adj-prep-adj-adv-1Pl-adj-prep-adv-prep-1Pl-adj

Soil oil that may separate us don't and separate from us don't

Kindness does not take us apart"

Phrase 'dael kuni' when translated lexically has the meaning as "fertile soil" because this phrase is seen in its contextual meaning 'dael kuni' that has its contextual meaning which is 'kindness'. While the words or other phrase in the sentence above is translated lexically.

3) deng in kil sulu ka mo in kil ai ka

PREP-PREP-V-N-ADJ-PREP-PREP-N-ADJ

From bringing torch that and which bring fire that

"The servants of God"

The words in italic and bold are words that must be translated contextually. If it is translated lexically, the meaning of word 'sulu' according to KBBI is 'thing that is used to brightened" and the word 'ai' means 'fire' so appropriate translation is contextual one. So, the words 'sulu' and 'ai' contextually give meaning that 'the servants' those are 
priests or other church hierarchy. While the words or other phrase in the sentence above is translated lexically.

4) sake se un tuip pa tia mo leten na tia

V-PREP-3Sg-N-ADJ-PREP-N-ADJ-ADV

Climb in he on he soon and mountain that soon

Soon go to his altar

The words in italic and bold are words that must be translated contextually. If it is translated lexically, the word 'tuip' means 'top' and the word 'leten' means 'mountain' so the appropriate translation is a contextual one which has the meaning 'go to the altar'. While the words and other phrase in the sentence above is translated lexically. Furthermore, the results of this study can be taken into translation techniques and its meaning. The meaning can be understood based on its cultural and sociolinguistics context.

\section{Discourse Analysis}

Discourse analysis of "Basan" then examines using Halliday's approach in three general semiotics meaning those are field, mode and tenor. The field of "Basan: is in social interaction (texts 1-4) and spiritual activities (texts 5-8). Tenor of "Basan" is it is done is by the leaders of the village to the guests in social occasion (text 1 and text 7 ) and by the priest to the assembly in religion occasions (text 13 and text 9). While, mode of "Basan' is it is done in verbally.

\section{CONCLUSIONS AND SUGGESTIONS}

\section{Conclusions}

Carrying out the maintenance and revitalization of oral literature is done objectively. To see the meaning contained in each speech and the context associated with the text spoken. The context in oral tradition "Basan" includes place, time, results and message which begins with an opening and ends with closing. While the meaning that can be applied in the oral tradition "Basan" are lexical and contextual meanings. The results of its discourse, "Basan" is done in verbally (mode), done by the leaders of the village to the guests in social occasion and by the priest to the assembly in religion occasion (tenor) and done in in social interaction and spiritual activities (field). 


\section{Suggestions}

The suggestion for further research is in analyzing the parallelism on phonology, morphology and semantics.

\section{REFERENCES}

Arikunto, S. (2017). Metodologi Penelitian Suatu Pendekatan Proposal. PT. Rineka Cipta.

Astika, I. M., \& Yasa, I. N. (2014). Sastra Lisan. Graha Ilmu.

Dea Rifia Bella. (2018). Bahasa Indonesia dalam Konteks: Lingua Franca di Pasar Barter oleh Orang Puor dan Lamalera di Lembata, Nusa Tenggara Timur. Antropologi Indonesia, 39(I), 39-58.

Kamus Bahasa Indonesia. (2008). Pusat Bahasa Departemen Pendidikan Nasional.

Maria, S. K. (2018). Wawi Wotik. II(2), 24-38.

Moleong, L. . (2014). Metode Penelitian Kualitatif(Edisi Revi). PT. Remaja Rosdakarya.

Mu'jizah. (2018). Preservasi Dan Revitalisasi Bahasa Dan Sastra Nafri, Papua: Sebuah Bahasa Hampir Punah. Aksara, 30(1), 75-88.

Sastrowardoyo, S., Damono, S. D., \& Achmad, A. K. (1985). Anthology of Asean literatures. Oral Literature of Indonesia. 455.

Tauk, D. (2016). Fonologi Bahasa Helong: Kajian Fonologi Generatif. Udayana University.

Taylor, S. J., Bogdan, R., \& DeVault, M. L. (2016). Introduction to Qualitative Research Method.

Wahyuni, D. (2017). Revitalisasi Sastra Bonai. Gramatika: Jurnal Ilmiah Kebahasaan Dan Kesastraan, 5(1), 64-74. https://doi.org/10.31813/gramatika/5.1.2017.94.64-74

Widyawati, F. (2019). Revitalisasi Tradisi Tombo Turuk Di Desa Perang Kabupaten Manggarai, Provinsi Nusa Tenggara Timur. Jurnal Pendidikan Dan Kebudayaan Randang Tana, 2(1), 30-38. 